\title{
Polybenzimidazole Confined in Semi-Interpenetrating Networks of Crosslinked Poly (Arylene Ether Ketone) for High Temperature Proton Exchange Membrane
}

\author{
Erli Qu ${ }^{1}$, Junqiao Jiang ${ }^{1}$, Min Xiao ${ }^{1} \mathbb{D}$, Dongmei Han ${ }^{1,2}$, Sheng Huang ${ }^{1}$, Zhiheng Huang ${ }^{1} \mathbb{D}$, Shuanjin Wang ${ }^{1, * \mathbb{D}}$ \\ and Yuezhong Meng ${ }^{1, *(1)}$
}

1 The Key Laboratory of Low-Carbon Chemistry \& Energy Conservation of Guangdong Province, State Key Laboratory of Optoelectronic Materials and Technologies, School of Materials Science and Engineering, Sun Yat-sen University, Guangzhou 510275, China; querli@mail2.sysu.edu.cn (E.Q.); jiangjq5@mail2.sysu.edu.cn (J.J.); stsxm@mail.sysu.edu.cn (M.X.); handongm@mail.sysu.edu.cn (D.H.); huangsh47@mail.sysu.edu.cn (S.H.); hzh29@mail.sysu.edu.cn (Z.H.)

2 School of Chemical Engineering and Technology, Sun Yat-Sen University, Zhuhai 519082, China

* Correspondence: wangshj@mail.sysu.edu.cn (S.W.); mengyzh@mail.sysu.edu.cn (Y.M.)

check for updates

Citation: Qu, E.; Jiang, J.; Xiao, M.; Han, D.; Huang, S.; Huang, Z.; Wang, S.; Meng, Y. Polybenzimidazole Confined in Semi-Interpenetrating Networks of Crosslinked Poly (Arylene Ether Ketone) for High Temperature Proton Exchange Membrane. Nanomaterials 2022, 12, 773. https://doi.org/10.3390/ nano12050773

Academic Editors: Ioannis V. Yentekakis and David Marrero-López

Received: 31 December 2021 Accepted: 23 February 2022 Published: 25 February 2022

Publisher's Note: MDPI stays neutral with regard to jurisdictional claims in published maps and institutional affiliations.

Copyright: () 2022 by the authors Licensee MDPI, Basel, Switzerland. This article is an open access article distributed under the terms and conditions of the Creative Commons Attribution (CC BY) license (https:// creativecommons.org/licenses/by/ $4.0 /)$.

\begin{abstract}
As a traditional high-temperature proton exchange membrane (HT-PEM), phosphoric acid (PA)-doped polybenzimidazole (PBI) is often subject to severe mechanical strength deterioration owing to the "plasticizing effect" of a large amount of PA. In order to address this issue, we fabricated the HT-PEMs with a crosslinked network of poly (arylene ether ketone) to confine polybenzimidazole in semi-interpenetration network using self-synthesized amino-terminated PBI $\left(\mathrm{PBI}-4 \mathrm{NH}_{2}\right)$ as a crosslinker. Compared with the pristine linear poly [2,2'-(p-oxdiphenylene)-5,5'-benzimidazole] (OPBI) membrane, the designed HT-PEMs (semi-IPN/ $x$ PBI), in the semi-IPN means that the membranes with a semi-interpenetration structure and $x$ represent the combined weight percentage of PBI-4NH $\mathrm{N}_{2}$ and OPBI. In addition, they also demonstrate an enhanced anti-oxidative stability and superior mechanical properties without the sacrifice of conductivity. The semi-IPN/70PBI exhibits a higher proton conductivity than OPBI at temperatures ranging from 80 to $180^{\circ} \mathrm{C}$. The HT-PEMFC with semi-IPN/70PBI exhibits excellent $\mathrm{H}_{2} / \mathrm{O}_{2}$ single cell performance with a power density of $660 \mathrm{~mW} \mathrm{~cm}^{-2}$ at $160{ }^{\circ} \mathrm{C}$ with flow rates of 250 and $500 \mathrm{~mL} \mathrm{~min}^{-1}$ for dry $\mathrm{H}_{2}$ and $\mathrm{O}_{2}$ at a backpressure of $0.03 \mathrm{MPa}$, which is $18 \%$ higher than that of OPBI $\left(561 \mathrm{~mW} \mathrm{~cm}^{-2}\right)$ under the same test conditions. The results indicate that the introduction of PBI containing crosslinked networks is a promising approach to improve the comprehensive performance of HT-PEMs.
\end{abstract}

Keywords: high-temperature proton exchange membrane; semi-interpenetration network; phosphoric acid; poly [2,2'-(p-oxdiphenylene)-5,5'-benzimidazole $]$

\section{Introduction}

In the last few decades, high temperature proton exchange membrane fuel cells (HTPEMFCs) with an operating temperature above $100{ }^{\circ} \mathrm{C}$ and a relative humidity below $50 \%$ have drawn increasing attention as advanced energy conversion devices, owing to their remarkable advantages of excellent thermal efficiency, high catalyst tolerance to $\mathrm{CO}$, rapid electrode kinetics, simple water-heat management systems, and so on [1-5]. As well established, the proton exchange membranes (PEMs) as the core part of HT-PEMFCs have an important impact on the lifespan and performance of fuel cells, which serves to transport protons and avoid fuel penetration from two electrodes [6-8]. Accordingly, HT-PEMs were extensively studied by many researchers in order to meet the advanced HTPEMFC technology $[9,10]$. To date, phosphoric acid-doped polybenzimidazole (PA-PBI) is rapidly becoming one of the most promising candidates to dominate the HT-PEMs prospect due to its favorable proton conductivity and its outstanding thermal and chemical stability 
without humidification conditions at elevated temperatures [11-14]. PA-PBI membrane has been widely investigated and developed since it was first reported by Wainright et al. in 1995 [15]. For PA-PBI membrane, the proton conductivity increases with increasing acid doping levels (ADLs). In far too many circumstances, a high PA doping level is essential to obtain the ideal proton conductivity for PA-PBI-based HT-PEMFCs. Nevertheless, excessive ADLs of the membranes result in the deterioration of mechanical strength, dimensional stability, and chemical stability on account of the "plasticizing effect" of the doped acid and the dissolution of PBI [16-19]. Moreover, excessive PA is apt to leach out in the period of cell operation due to the condensation of water in the cathode, which in turn worsens the cell performance [20-22]. The above two key aspects restrict the practical application of PBI-based membranes for PEMs.

In order to address the trade-off between proton conductivity and mechanical strength of PA doped PBI-based membranes, many attempts have been made, such as preparing cross-linked membranes [23], copolymerization membranes [24], acid-base blend membranes [25], and hybrid membranes with inorganic fillers [26]. Among these methods, cross-linking has been proven to be a significant approach to strengthen the comprehensive performance of PA-PBI membranes as HT-PEMs, notably in the respect of oxidative stability, acid retention ability, anti-degradation, and mechanical strength/dimensional stability [27-32], because it can connect chemical bonds and polymer molecules by chemical bonds to form a network or body structure. Over the past decades, the research on cross-linked PBI has been a concern of researchers. However, there are two issues that need to be taken seriously. On the one hand, the cross-linked membranes with a high crosslinking degree will be brittle and difficult to prepare. On the other hand, the PA absorption of the cross-linked membranes will be restricted because cross-linking leads to a compact molecular chain in the membranes [20,33]. For instance, Li et al. reported that the ADL of the as-prepared cross-linked PBI membranes via p-xylene dibromide cross-linking agent reduced from 15.5 to 8.5 PA per unit, compared with the linear PBI membrane [34]. Kim et al. prepared a crosslinked $\mathrm{P}(\mathrm{pBUa}-\mathrm{co}-\mathrm{BI})-20$ membrane, however, its conductivity was 30\% lower than that of original PBI [35]. Moreover, the conventional cross-linker is utilized at the expense of the concentration of active $\mathrm{N}-\mathrm{H}$ groups, and with the amount of crosslinking agents increasing, a more compact product will be produced [36,37]. These negative factors will inevitably reduce ADLs, and consequently, decrease the proton conductivity and weaken the single-cell performance [38-40]. For example, compared with pure PBI, the ADL of a crosslinked PBI membrane dropped from 13.9 to 10.3 , thus leading to a sharp decrease in conductivity from $144 \mathrm{mS} \mathrm{cm}^{-1}$ to $66 \mathrm{mS} \mathrm{cm}^{-1}$ at $180{ }^{\circ} \mathrm{C}$ [30]. Therefore, to obtain higher proton conductivity under lower acid uptake and to enhance fuel cell performance, it is crucial to design and develop a new crosslinking agent without the elimination of $\mathrm{N}-\mathrm{H}$ group on the imidazole ring.

Poly (arylene ether ketone) (PAEK) in particular is well known as an ideal PEM supplementary material, because of its excellent mechanical strength, favorable thermal stability, outstanding solubility, and suitability for mass production [41-44]. Furthermore, poly [2,2'-(p-oxdiphenylene)-5,5'-benzimidazole] (OPBI) has been widely studied because it contains ether bonds, which are conducive to the absorption of PA and proton conduction.

In this work, we prepared HT-PEMs (semi-IPN/ $x \mathrm{PBI}$ ) with a semi-interpenetration structure, in which the linear OPBI is confined in the crosslinked network of PAEK by a designed PBI-based crosslinker (PBI-4NH $\left.\mathrm{N}_{2}\right)$. A kind of neoteric crosslinking agent PBI$4 \mathrm{NH}_{2}$ with amino ended-groups was designed and synthesized, which can provide active imidazole groups in the crosslinked network. Compared to the pristine linear OPBI, the resultant semi-IPN $/ x$ PBI exhibited superior physicochemical stabilities. Upon doping PA, the composite membrane presents an enhanced electrochemical performance. 


\section{Experimental}

\subsection{Materials}

Poly [2,2'-(p-oxdiphenylene)-5,5'-benzimidazole] (OPBI, $6000 \mathrm{~Pa} \cdot \mathrm{S}$ ) was purchased from Shanghai Shengjun Plastic Technology Co., Ltd. (Shanghai, China). Phenolphthalin (PPL), 3,3'-Diaminobenzidine (DAB, 97\%), isophthalic acid (IPA), and 4,4'-difluorobenzophenone (99\%) were acquired from Shanghai Macklin Biochemical Co. Ltd. (Shanghai, China). Anhydrous potassium carbonate $\left(\mathrm{K}_{2} \mathrm{CO}_{3}\right)$, hydrochloric acid $(\mathrm{HCl})$, and toluene were obtained from Guangzhou Chemical Reagent Factory (Guangzhou, China). Phosphoric acid solution (85 wt.\%), phosphorus pentoxide $\left(\mathrm{P}_{2} \mathrm{O}_{5}\right)$, polyphosphoric acid (PPA), N, NDimethylacetamide (DMAc), and 1-Methyl-2-pyrrolidinone (NMP) were purchased from Aladdin Chemistry Co. Ltd. (Shanghai, China). Ammonia solution (25 wt.\%) was acquired from Tianjin Fuyu Fine Chemical Co. Ltd. (Tianjin, China). All the materials were acquired commercially and utilized as received.

\subsection{Methods}

2.2.1. Preparation of Poly (Arylene Ether Ketone) with Pendant Carboxyl Groups (PAEK-COOH)

As depicted in Scheme 1a, PAEK-COOH was prepared via a typical nucleophilic aromatic substitution reaction. The detailed polycondensation reaction presented here was performed as follows: 4, $4^{\prime}$-difluorobenzophenone $(2.18 \mathrm{~g}, 10 \mathrm{mmol})$, PPL (3.20 g, $\left.10 \mathrm{mmol}\right)$, and $\mathrm{K}_{2} \mathrm{CO}_{3}(3.46 \mathrm{~g}, 30 \mathrm{mmol})$ were added to a $150 \mathrm{~mL}$ three-neck round-bottomed flask furnished with a Dean-Stark trap containing a reflux condenser, a magnetic stirrer, and a nitrogen inlet. In the meanwhile, DMAc and toluene were added as the solvent and water removal system to form a solid concentration of $21 \mathrm{wt} . \%$. The reaction mixture was firstly stirred and maintained at the reflux temperature of about $140{ }^{\circ} \mathrm{C}$ for $4-5 \mathrm{~h}$ so that the water was completely removed from the reaction system, and then the toluene was removed. Next, the reaction temperature was slowly promoted to $170{ }^{\circ} \mathrm{C}$ and maintained for about $24 \mathrm{~h}$ until the polymerization was completed, during which the reaction solution became more viscous. After cooling to room temperature, the reacted viscous solution was precipitated in the mixed solution of concentrated $\mathrm{HCl}, \mathrm{CH}_{3} \mathrm{OH}$, and deionized water and stirred vigorously. The resulting threadlike polymer was further crushed into powder through a high-speed blender and filtered. Finally, the light green powder was washed several times sequentially using deionized water and ethanol, respectively, and dried in a vacuum oven at $100{ }^{\circ} \mathrm{C}$ for $24 \mathrm{~h}$.

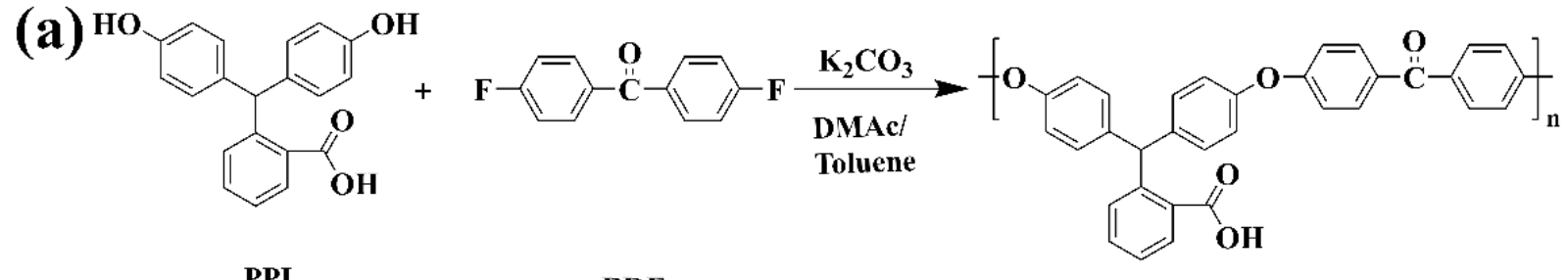

PPL

BDF

PAEK-COOH

\section{(b)}<smiles>Nc1ccc(-c2ccc(N)c(N)c2)cc1N</smiles><smiles>Nc1ccc(-c2ccc3[nH]c(-c4cccc(-c5nc6ccc(-c7ccc(N)c(N)c7)cc6[nH]5)c4)nc3c2)cc1N</smiles>

PBI-4NH

Scheme 1. Synthesis of (a) PAEK-COOH, and (b) PBI-4NH 2 . 


\subsubsection{Preparation of Amino-Ended Crosslinker $\left(\mathrm{PBI}-4 \mathrm{NH}_{2}\right)$}

As shown in Scheme 1b, a crosslinker of PBI- $4 \mathrm{NH}_{2}$ was prepared by means of a condensation reaction between isophthalic acid (IPA) and 3,3'-diaminobenzidine (DAB) using PPA as a catalyst and dehydrating agent. The specific implementation process is as follows: firstly, $81 \mathrm{~g}$ of PPA and $21 \mathrm{~g}$ of $\mathrm{P}_{2} \mathrm{O}_{5}$ were put into a $150 \mathrm{~mL}$ three-neck roundbottomed flask equipped with a mechanical stirrer and a nitrogen inlet and outlet. Then, the mixture was stirred at $120{ }^{\circ} \mathrm{C}$ for approximately $4 \mathrm{~h}$ until the solution was transparent. Secondly, the solution was cooled to room temperature, and DAB (3.8569 $\mathrm{g}, 18 \mathrm{mmol})$ was added to the flask and stirred at $150{ }^{\circ} \mathrm{C}$ to dissolve it completely. Next, IPA (1.4952 g, $9 \mathrm{mmol}$ ) was added in batches and stirred for $2 \mathrm{~h}$ at $150^{\circ} \mathrm{C}$. Finally, the reaction temperature was increased to $190{ }^{\circ} \mathrm{C}$ and kept for another $22 \mathrm{~h}$. After the condensation reaction, the viscous solution was slowly poured into ice deionized water. In order to neutralize the excess phosphoric acid, a dilute solution of ammonium hydroxide (10 wt.\%) was used to adjust the $\mathrm{pH}$ to neutral. In the last step, the resulting oligomer was filtered, washed with distilled water several times, and dried using a freeze dryer at $-60{ }^{\circ} \mathrm{C}$ for $48 \mathrm{~h}$ so that the residual solvent was completely removed.

\subsubsection{Preparation of Semi-IPN/ $x$ PBI Membranes}

As depicted in Scheme 2, the designed membranes with a semi-IPN structure were prepared by the solution casting method with an in situ crosslinking reaction between PAEK$\mathrm{COOH}$ and PBI- $4 \mathrm{NH}_{2}$. The obtained membranes are named semi-IPN/ $x$ PBI, in which semi-IPN means the membranes with a semi-interpenetration structure, and $x$ represents the combined weight percentage of PBI- $4 \mathrm{NH}_{2}$ and OPBI. For an easier comparison, the pure OPBI membrane and the fully crosslinked membrane of PAEK-COOH and PBI- $4 \mathrm{NH}_{2}$ (denoted as PAEK-cr-PBI) were also prepared separately. The details are depicted as follows.

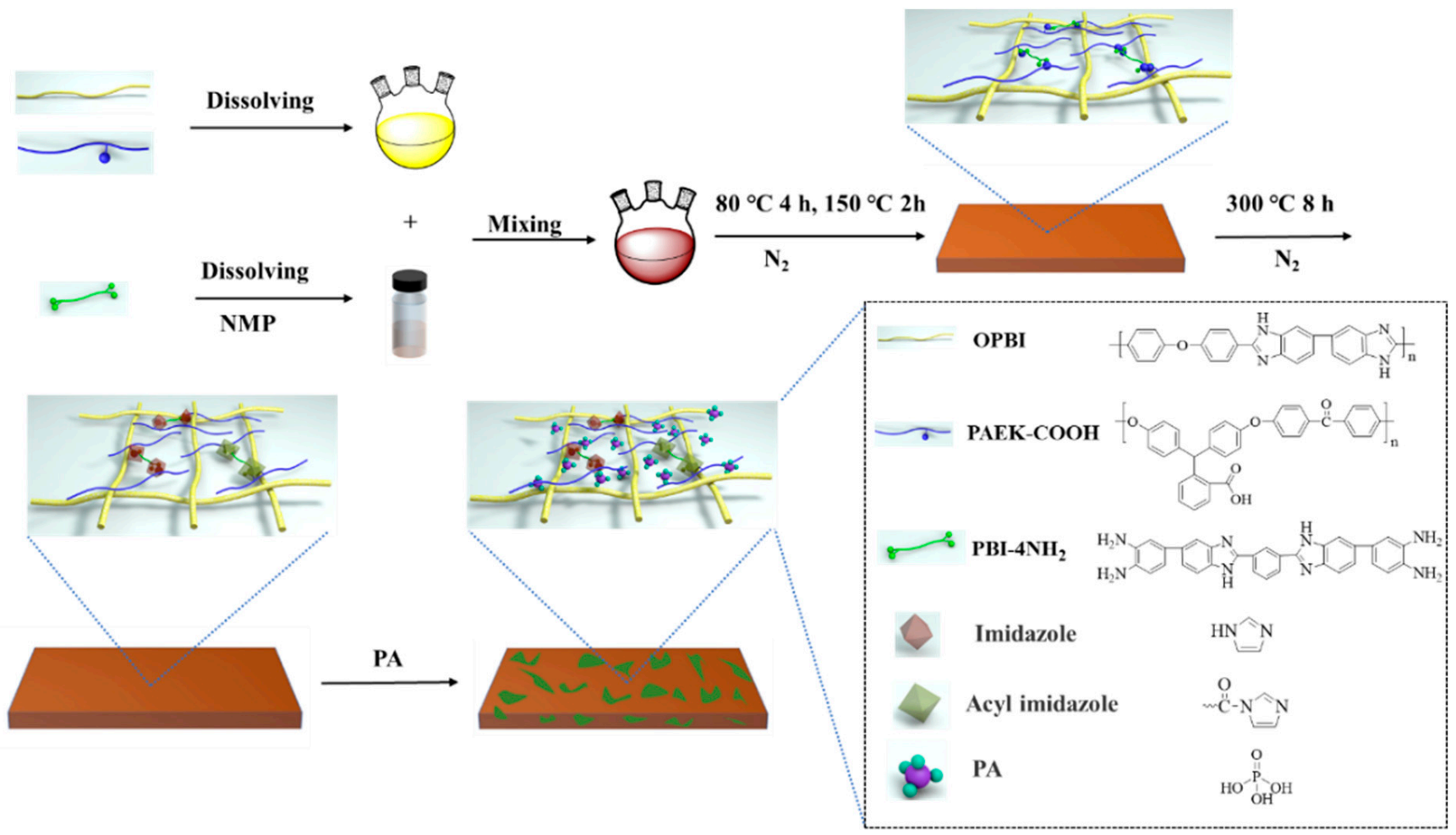

Scheme 2. Preparation of semi-IPN/ $x$ PBI membranes.

OPBI membrane: $1.0 \mathrm{~g}$ OPBI powder was dissolved in $10 \mathrm{~mL}$ NMP solvent under continuous magnetic stirring at $80{ }^{\circ} \mathrm{C}$ for $12 \mathrm{~h}$ to form a transparent claybank polymer 
solution, and then naturally cooled to room temperature. The solution was cast on a clean glass plate and then treated at $80{ }^{\circ} \mathrm{C}$ for $12 \mathrm{~h}$ to obtain OPBI membrane.

PAEK-cr-PBI membrane: the molar ratio of the carboxyl groups of PAEK-COOH to the amino groups of PBI-4NH $\mathrm{N}_{2}$ was 1:2. PAEK-COOH $(746.3 \mathrm{mg})$ and $\mathrm{PBI}-4 \mathrm{NH}_{2}(392.0 \mathrm{mg})$ were dissolved into $5 \mathrm{~mL}$ and $3 \mathrm{~mL} \mathrm{NMP}$, respectively. Subsequently, the solution of $\mathrm{PBI}-4 \mathrm{NH}_{2}$ was added into PAEK-COOH solution drop by drop under vigorous magnetic stirring. After that, the mixed solution was stirred at $80{ }^{\circ} \mathrm{C}$ for $4 \mathrm{~h}$ and $150{ }^{\circ} \mathrm{C}$ for $2 \mathrm{~h}$ under $\mathrm{N}_{2}$ atmosphere to complete the pre-crosslinking process. After that, the pre-crosslinking solution was cooled to about $60^{\circ} \mathrm{C}$ and cast onto a clean glass plate and heated at $80{ }^{\circ} \mathrm{C}$ for $12 \mathrm{~h}$ to volatilize the solvent to obtain the pre-crosslinked membrane. Next, the asprepared pre-crosslinked membrane was further treated under $\mathrm{N}_{2}$ atmosphere at $300{ }^{\circ} \mathrm{C}$ for $8 \mathrm{~h}$ (heating rate: $10{ }^{\circ} \mathrm{C} \mathrm{min}^{-1}$ ) to complete the full cross-linking reaction between PAEK-COOH and PBI-4NH 2 . For PAEK-COOH, the ion-exchange capacity (IEC) value of active $-\mathrm{COOH}$ is $2.01 \mathrm{mmol} \mathrm{g}^{-1}$. The $\mathrm{PBI}-4 \mathrm{NH}_{2}$ crosslinker possesses two pair of diamino groups, it can connect the carbonxylic acid groups in different PAEK polymer chains and then result in a crosslinked structure. After crosslinking, all carboxylic acid groups reacted with amino groups to afford new imidazole groups to absorb PA molecules by acid-base interaction during PA immersing. The capacity of imidazole group in PAEK-cr-PBI is calculated as $2.64 \mathrm{mmol} \mathrm{g}^{-1}$.

Semi-IPN/ $x$ PBI membranes: PAEK-COOH and OPBI were firstly dissolved in NMP at $80{ }^{\circ} \mathrm{C}$ to form a transparent solution. Then, a solution with a specific amount of PBI$4 \mathrm{NH}_{2}$ in NMP was added dropwise into the above solution with a total solid content of approximately $10 \mathrm{wt} . \%$, and the requisite content of PAEK-COOH, PBI- $4 \mathrm{NH}_{2}$, and OPBI was controlled. Following this, a solution of PAEK-COOH, OPBI, and PBI- $4 \mathrm{NH}_{2}$ in $\mathrm{NMP}$ was obtained for fabricating semi-IPN $/ x$ PBI membranes using the same preparation procedure of PAEK-cr-PBI membrane.

\subsection{Characterization and Measurements}

2.3.1. Characterization of Chemical Structure

${ }^{1} \mathrm{H}$ NMR spectra of PBI-4NH $\mathrm{NH}_{2}$ and PAEK-COOH were collected by a Bruker DRX500 spectrometer (PerkinElmer Inc., Waltham, MA, USA) utilizing deuterated dimethyl sulfoxide (DMSO- $\mathrm{d}_{6}$ ) as the solvent and tetramethylsilane (TMS) as the internal standard.

Fourier transform infrared (FT-IR) spectroscopy of the membranes involved in our work was conducted on a Thermo Scientific Nicolet 6700 FT-IR spectrometer (Nicolet, Waltham, MA, USA) with a wavenumber range of $4000-650 \mathrm{~cm}^{-1}$. The molecular weight of the synthesized PAEK-COOH was measured by gel permeation chromatography (GPC) (Headwaters Incorporated, South Jordan, UT, USA) which includes a Waters 1515 iscoratic HPLC pump, a Waters 717 plus autosampler and a Waters 2417 refractive index detector. DMF was used as the solvent at a flow rate of $1 \mathrm{~mL} / \mathrm{min}$ at room temperature. The concentration of PAEK-COOH dissolved in DMF was $1 \mathrm{mg} / \mathrm{mL}$.

\subsubsection{Thermal Stability}

Thermogravimetric analysis (TGA) curves of the membranes were performed using a Pyris 1 TGA analyzer from the Perkin Elmer company (PerkinElmer Inc., Waltham, MA, USA), and during the testing, the temperature was raised from room temperature to $600{ }^{\circ} \mathrm{C}$ at a heating rate of $10^{\circ} \mathrm{C} \mathrm{min}^{-1}$ along with the $\mathrm{O}_{2}$ flow of $25 \mathrm{~mL} \mathrm{~min}^{-1}$. Before testing, all the dry membranes were preserved in a vacuum drying chamber at $120{ }^{\circ} \mathrm{C}$ for $12 \mathrm{~h}$ to completely remove residual organic solvents and the chemically bound water.

\subsubsection{Gel Fraction Test}

A gel fraction test of semi-IPN/ $x$ PBI membranes was carried out by solvent extraction to reflect the crosslinking degree. OPBI and PAEK-cr-PBI membranes were also measured for comparison. The gel content was estimated from the residual mass of the membranes after soaking them in NMP solvent at $100{ }^{\circ} \mathrm{C}$ for $48 \mathrm{~h}$. Before testing, the mass of the dried 
membranes was denoted as $W_{1}$. After the test, the membranes were washed several times using deionized water and then dried at $120^{\circ} \mathrm{C}$ for $24 \mathrm{~h}$ in the vacuum drying oven until the mass was constant. They were then reweighed $\left(W_{2}\right)$. The Gel fraction is calculated using following equation:

$$
\text { Gel fraction }(\%)=W_{2} / W_{1} \times 100
$$

\subsubsection{PA Uptake and Volumetric Swelling Ratio}

The PA uptake and volumetric swelling ratio of the membranes were calculated by virtue of measuring the changes between the wet and dry weight and dimension of the membranes. Dried OPBI, PAEK-cr-PBI, and semi-IPN $/ x$ PBI membranes were used for testing. Before PA doping, all membranes were dried at $100{ }^{\circ} \mathrm{C}$ for $24 \mathrm{~h}$ in a vacuum drying oven to reach constant weight, and then the weight, length, width, and thickness of the acid-undoped dry membranes were recorded, respectively. After that, the dry membranes were immersed in $85 \mathrm{wt} . \%$ PA solution at $120^{\circ} \mathrm{C}$ for $15 \mathrm{~h}$. Excess PA on the surface of the membranes was immediately wiped with tissue paper as soon as they were taken out of the PA solution, and their corresponding weight and size were measured. The PA-doped membranes were dried at $100{ }^{\circ} \mathrm{C}$ for $12 \mathrm{~h}$ in a vacuum drying oven to get rid of the bound water, and their weight and dimension were recorded. A total of three samples were taken for each membrane to acquire the average value.

Finally, the PA uptake and volumetric Swelling ratio of the membranes was calculated according to the following equations

$$
\begin{aligned}
& \text { PA uptake }(\%)=\frac{W_{\text {doped }}-W_{\text {undoped }}}{W_{\text {doped }}} \times 100 \\
& \text { Swelling ratio }(\%)=\frac{V_{\text {wet }}-V_{\text {undoped }}}{V_{\text {undoped }}} \times 100
\end{aligned}
$$

where $W_{\text {undoped }}$ and $W_{\text {doped }}$ are the weight and volume of the dry membrane and PAdoped membrane, respectively. $V_{\text {undoped }}$ and $V_{\text {doped }}$ are assigned to the volume of the dry membrane and PA-doped membrane, respectively.

\subsubsection{Evaluation of Oxidative Stability}

The oxidative stability of PEMs has generally been assessed by oxidative radicals to suggest the long-term durability of the membranes. OPBI, PAEK-cr-PBI, and semi$\mathrm{IPN} / x$ PBI membranes were submersed in a Fenton reagent $\left(3 \mathrm{wt} . \% \mathrm{H}_{2} \mathrm{O}_{2}\right.$ solution containing $4 \mathrm{ppm} \mathrm{Fe}{ }^{2+}$ ) at $80{ }^{\circ} \mathrm{C}$ for $48 \mathrm{~h}$, then the samples were collected, rinsed with deionized water, and dried in an oven at $120^{\circ} \mathrm{C}$ for $24 \mathrm{~h}$. To ensure the accuracy of the results, three samples were treated in parallel for each membrane, and the final results were averaged. The oxidative stability $(O S, \%)$ was calculated by the retained weight after immersion using Equation (4):

$$
\text { OS }(\%)=W_{4} / W_{3} \times 100
$$

where $W_{3}$ is the weight of the sample before the test and $W_{4}$ is the residue weight of the membrane after the test.

\subsubsection{Mechanical Properties}

The mechanical properties of PA doped OPBI, PAEK-cr-PBI, and semi-IPN/xPBI membranes were investigated by a universal testing instrument (New SANS, Shenzhen, China), and the membrane samples (40-50 $\mathrm{mm}$ length and 4-6 mm width) were conducted at room temperature at a constant strain rate of $5 \mathrm{~mm} \mathrm{~min}^{-1}$. Prior to testing, the samples were dried at $100{ }^{\circ} \mathrm{C}$ for $24 \mathrm{~h}$. For each data item obtained, at least three samples were tested to obtain an average value. 


\subsubsection{Proton Conductivity}

The proton conductivities of PA doped membranes were measured via a four-electrode AC impedance method employing a PGSTAT204 electrochemical workstation (AUT50992, AUTOLAB) with a frequency range of $0.1 \mathrm{~Hz}$ to $1 \times 10^{5} \mathrm{~Hz}$. The impedance measurement of rectangular membrane samples was performed in the absence of humidification with a temperature range of $80 \sim 180^{\circ} \mathrm{C}$. The conductivity $\sigma\left(\mathrm{S} \mathrm{cm}^{-1}\right)$ was calculated from the following equation:

$$
\sigma=\frac{L}{R \times A}
$$

where $L(\mathrm{~cm}), A\left(\mathrm{~cm}^{2}\right)$, and $R(\Omega)$ are the distance between two electrodes, the crosssectional area of the membranes, and the membrane resistance derived from the Nyquist plot, respectively.

\subsubsection{Single Cell Test}

The PA doped membranes were applied to fabricate membrane electrode assemblies (MEAs) with an active area of $5 \mathrm{~cm}^{2}$. The $1.0 \mathrm{mg} \mathrm{cm}^{-2} \mathrm{Pt} / \mathrm{C}$ electrodes were purchased from Shanghai Hensen Company (Shanghai, China). The single cell performance was operated on a fuel cell testing system for dry $\mathrm{H}_{2}$ and $\mathrm{O}_{2}$ before and after optimizing test conditions.

\section{Results and Discussion}

\subsection{Chemical Structure Identification}

With regard to the characterization of molecular weight correlation, the GPC results show the number-average molar mass, $\mathrm{Mn}=159,500 \mathrm{~g} \mathrm{~mol}^{-1}$, the weight-average molar mass, $\mathrm{Mw}=162,600 \mathrm{~g} \mathrm{~mol}^{-1}$, and the polydispersity, $\mathrm{PDI}=1.02$, suggesting a high molecular weight acquired, which is the prerequisite for the formation of a membrane.

The unambiguous structure of PAEK-COOH and PBI- $4 \mathrm{NH}_{2}$ was identified by a ${ }^{1} \mathrm{H}$ NMR (500 MHz, DMSO-d $\mathrm{d}_{6}$ ) spectrum, as shown in Figure 1 For PAEK-COOH (Figure 1a). The chemical shift at $6.68-7.80 \mathrm{ppm}$ is attributed to the aromatic protons, and the peak at about $13.05 \mathrm{ppm}$ is assigned to the proton in the carboxylic acid group. Similarly, for PBI- $4 \mathrm{NH}_{2}$ (Figure $1 \mathrm{~b}$ ), the associated signal peaks are assigned from number 1 to 11 . The two peaks at 13.07 and $13.25 \mathrm{ppm}$ are designated as the imidazole proton. The signal peaks appearing in between 6.63 and $6.93 \mathrm{ppm}$ are attributed to the terminal aromatic proton. Furthermore, the peaks in the range of $8.05-9.16 \mathrm{ppm}$ correspond to protons of the benzene ring between two benzimidazole rings. At the same time, the benzene ring protons adjacent to the imidazole ring are at between 7.41 and $7.83 \mathrm{ppm}$, and the proton peak of terminal amine emerged at $4.61 \mathrm{ppm}$. The above analysis indicates that the structure of PAEK-COOH and PBI- $4 \mathrm{NH}_{2}$ are in good agreement with the spectral data.

For PBI- $4 \mathrm{NH}_{2}$, the typical characteristic absorption peaks at $3066 \mathrm{~cm}^{-1}, 1626 \mathrm{~cm}^{-1}$, $1446 \mathrm{~cm}^{-1}$, and $1285 \mathrm{~cm}^{-1}$ are ascribed to the stretching vibration of the $-\mathrm{NH}_{2}$ or $-\mathrm{NH}$ group, the in-plane $\mathrm{C}=\mathrm{C}$ deformation of benzimidazole rings, and the $\mathrm{C}=\mathrm{N}$ and $\mathrm{C}-\mathrm{N}$ stretching vibrations of imidazole, respectively. Additionally, the absorption bands at approximately $1101 \mathrm{~cm}^{-1}$ and $802 \mathrm{~cm}^{-1}$ imply the existence of the benzene ring. These features indicate that the PBI- $4 \mathrm{NH}_{2}$ has been successfully prepared. For PAEK-COOH, the main vibration peaks of the carbonyl $(\mathrm{C}=\mathrm{O})$ stretching of the carboxylic acid group $\left(1722 \mathrm{~cm}^{-1}\right)$ and ketone $\left(1652 \mathrm{~cm}^{-1}\right)$ can be obviously observed. Meanwhile, a significant absorption band centered at $1161 \mathrm{~cm}^{-1}$ matches with the Ar-O-Ar linkage, manifesting the successful synthesis of PAEK-COOH. After heat treatment at $300{ }^{\circ} \mathrm{C}$ (PAEK-COOH-300 ${ }^{\circ} \mathrm{C}$ ), the absorption peak of the carboxylic acid groups at $1722 \mathrm{~cm}^{-1}$ disappears and a new vibration peak appears at $1771 \mathrm{~cm}^{-1}$, which may be due to the dehydration between the carboxylic acid groups to form anhydride carbonyl. Similarly, for the pre-crosslinked membrane (PAEKcr-PBI- $150{ }^{\circ} \mathrm{C}$ ), the disappearance of the $-\mathrm{COOH}$ absorption peak is due to the reaction of $-\mathrm{COOH}$ and $-\mathrm{NH}_{2}$ to yield the amide group. Thereafter, a new vibration peak at $1765 \mathrm{~cm}^{-1}$ may be attributed to the formation of acyl imidazole. In addition, it is worth noting that the vibration bands of $\mathrm{C}=\mathrm{N}$ or $\mathrm{C}-\mathrm{N}$ are superimposed by other function groups in the 
backbone of the crosslinked membrane and they are not recognized from PAEK-COOH. The disappearance of the strong absorption band of $-\mathrm{COOH}$ also hints that $-\mathrm{COOH}$ groups are converted into benzimidazole groups. Therefore, it can be inferred from the above discussion that two reactions occur during the crosslinking process, and the possible reaction scheme is depicted in Scheme 3. A model reaction (Figure S1 and Scheme S1 in Supplementary Materials) was designed to further confirm the possible reactions, and the results are consistent with the above hypotheses.

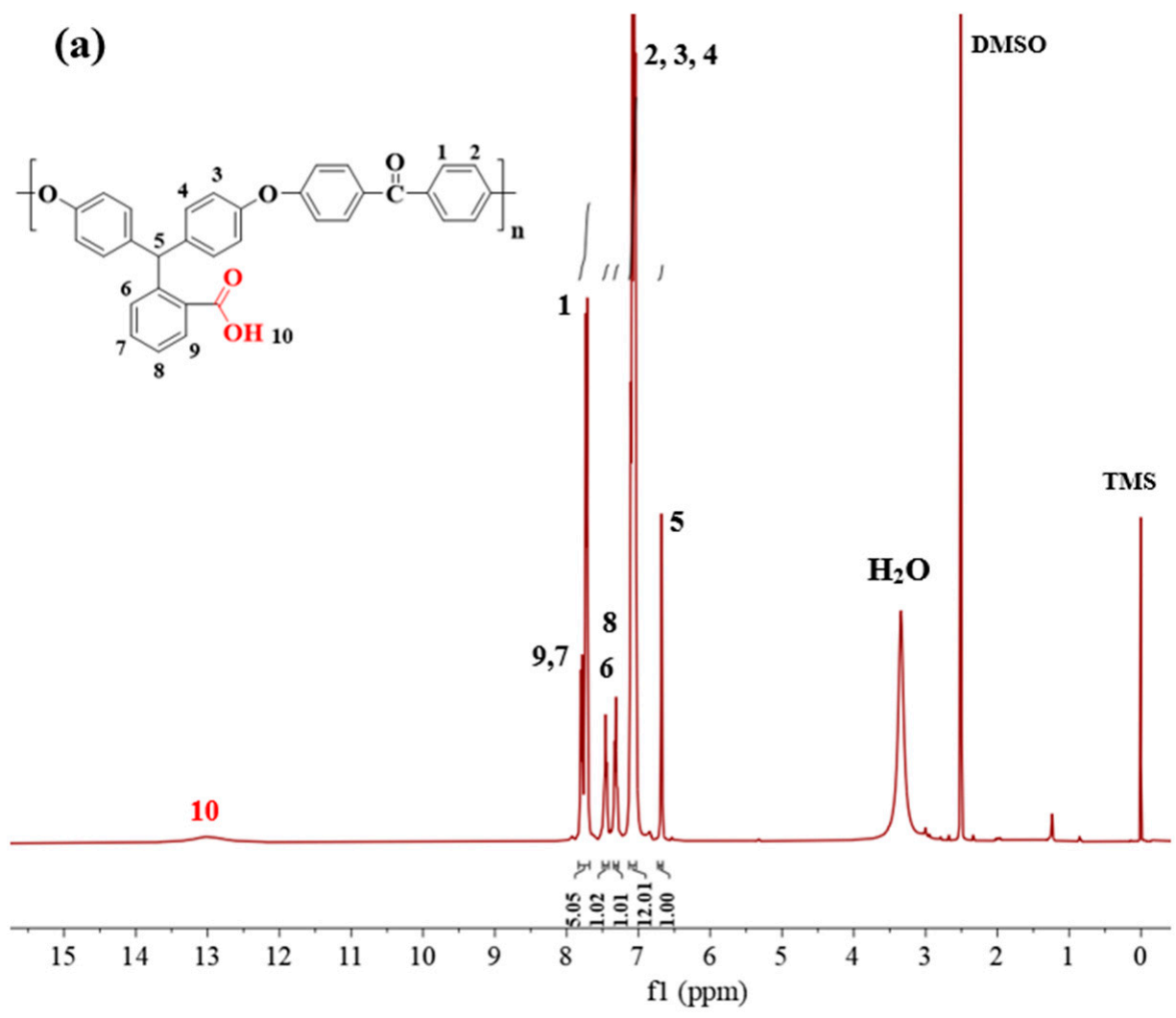

(b)
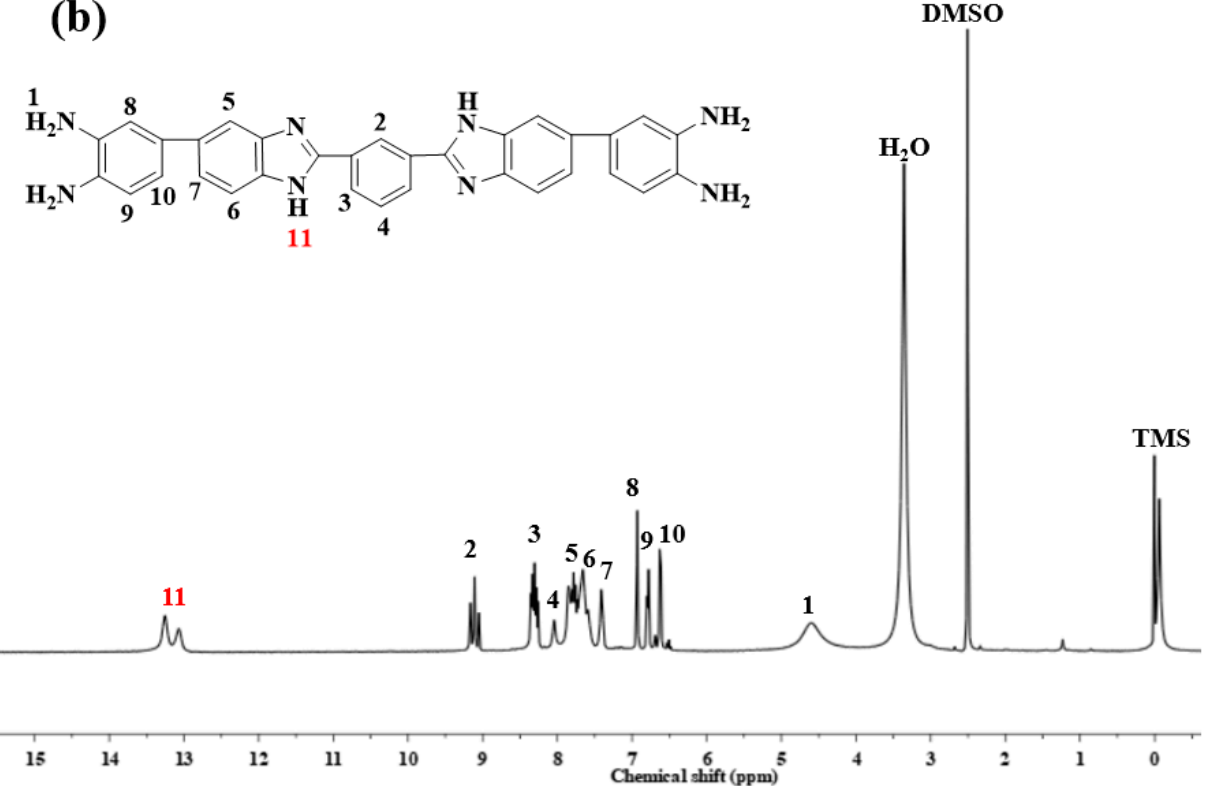

Figure 1. ${ }^{1} \mathrm{H}$ NMR spectra of (a) PAEK-COOH, and (b) PBI- $4 \mathrm{NH}_{2}$ in DMSO-d 6 . 
The structure changes of PAEK-COOH and PBI- $4 \mathrm{NH}_{2}$ before and after crosslinking were also verified by FT-IR to speculate the possible mechanism of the reaction, as presented in Figure 2.

The crosslinked network will result in the insolubility of membranes in common organic solvent. The gel fractions test was performed to evaluate the cross-linking degree of PAEK-cr-PBI and semi-IPN/ $x$ PBI, and the results are shown in Figure 3. After soaking in NMP for $48 \mathrm{~h}$ at $100{ }^{\circ} \mathrm{C}$, it can be clearly observed that semi-IPN/ $x$ PBI membranes keep almost wholly intact, while the pure OPBI membrane is entirely dissolved. The gel fractions of PAEK-cr-PBI, semi-IPN/70PBI, and semi-IPN/60PBI membranes were $95.6 \%, 92.5 \%$, and $94.0 \%$, respectively. Moreover, with the increase of OPBI content, the residual weight did not decrease significantly, indicating that the construction of a 3D network structure has a certain inhibitory effect on the molecular chain movement of OPBI.

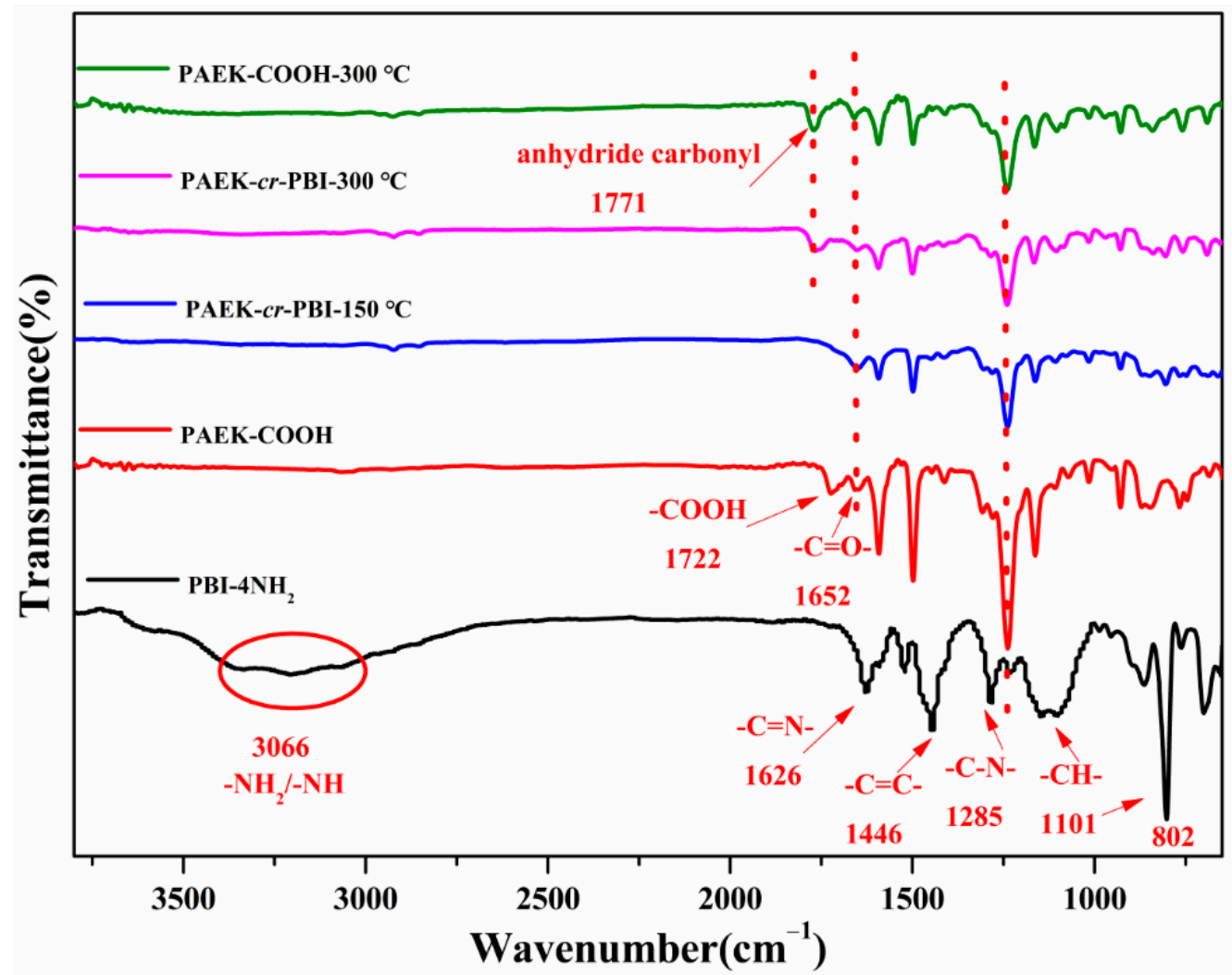

Figure 2. FT-IR spectra of PAEK-COOH, PBI- $4 \mathrm{NH}_{2}$, and PAEK-cr-PBI with different treatment temperatures.

\subsection{Thermal and Oxidative Stability}

The thermal stability of the membranes before and after PA doping was evaluated using TGA under $\mathrm{O}_{2}$ atmosphere. As shown in Figure $4 \mathrm{a}$, the thermal decomposition temperatures of PAEK-cr-PBI and semi-IPN/70PBI are higher than those of OPBI, implying that the crosslinked structure induced by crosslinker PBI- $4 \mathrm{NH}_{2}$ enhances their thermal stability. Additionally, TGA profiles of PA, PA doped OPBI, and semi-IPN/70PBI membranes under $\mathrm{O}_{2}$ atmosphere are also presented in Figure $4 \mathrm{~b}$. After doping PA, both membranes lost weight at about $160{ }^{\circ} \mathrm{C}$ due to PA dehydration. For PA, the weight decreases from $85 \%$ to $67 \%$ from $160{ }^{\circ} \mathrm{C}$ to $500{ }^{\circ} \mathrm{C}$, resulting in a loss of $18 \%$ total weight. For PA doped OPBI membrane, the weight decreases from $77 \%$ to $66 \%$ from $160{ }^{\circ} \mathrm{C}$ to $500{ }^{\circ} \mathrm{C}$, resulting in a loss of $11 \%$ total weight. According to the theoretical calculation, the weight loss due to PA dehydration is up to $13 \%$. For PA doped semi-IPN/70PBI composite membrane, the weight decreases from $81 \%$ to $69 \%$ from $160{ }^{\circ} \mathrm{C}$ to $500{ }^{\circ} \mathrm{C}$, resulting in a loss of $12 \%$ total weight. According to the theoretical calculation, the weight loss due to PA dehydration is up to 
$12 \%$. The theoretical value and the experimental value are within the allowable range of error, indicating that the degradation of the polymer membrane itself can be observed over a temperature range similar to that of the PA undoped polymer membrane. Meanwhile, the $5 \%$ weight loss temperatures $\left(\mathrm{T}_{-5 \%}\right)$ for dry membranes under $\mathrm{O}_{2}$ atmosphere determined by TGA are listed in Table 1 . The $\mathrm{T}_{-5} \%$ is all above $300{ }^{\circ} \mathrm{C}$, indicating that the thermal stability of each sample can guarantee their application in HT-PEMs.
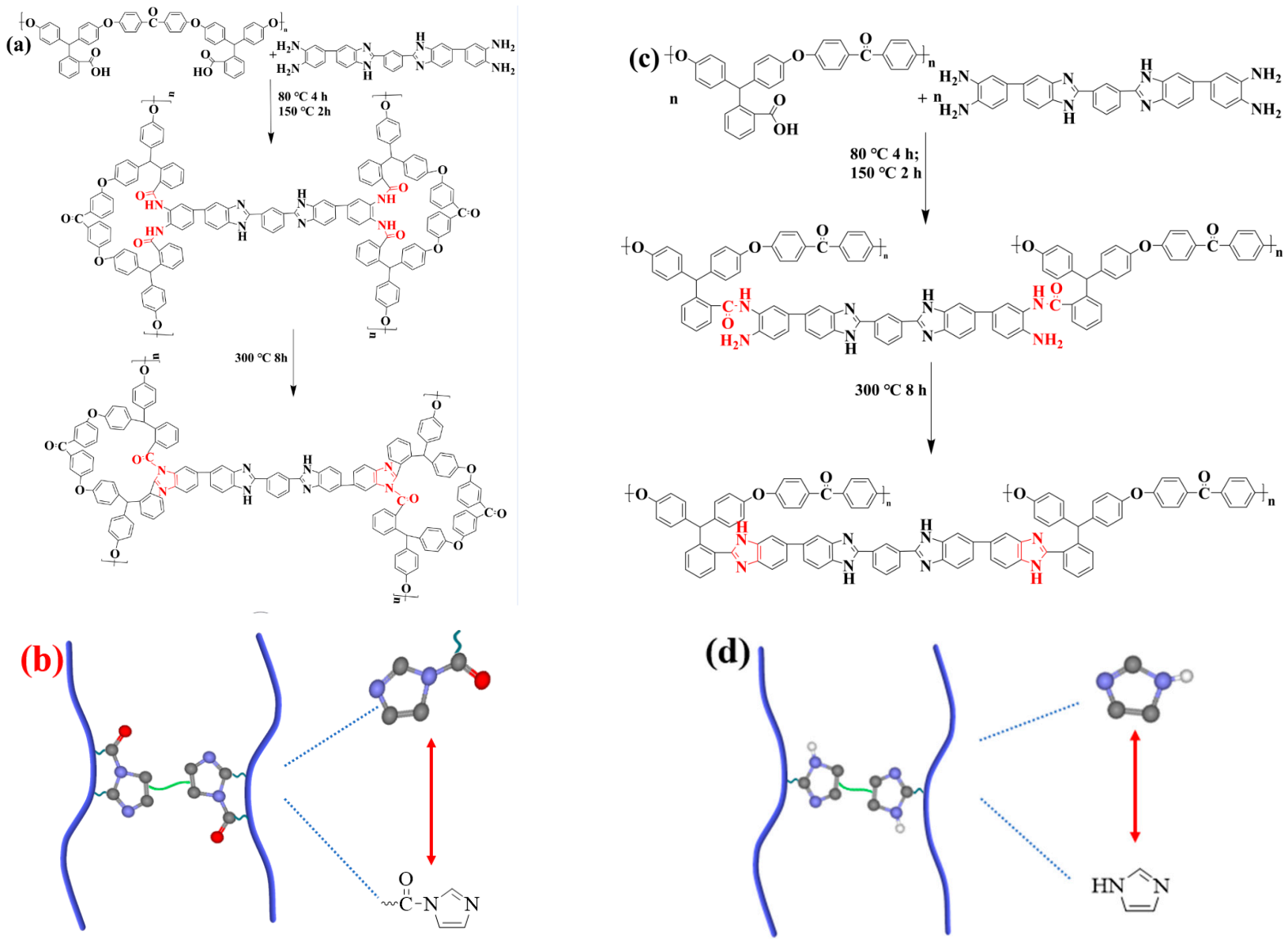

Scheme 3. Cross-linking mechanism and corresponding structure diagram of PAEK-cr-PBI membrane to form acyl benzimidazole $(\mathbf{a}, \mathbf{b})$ and benzimidazole $(\mathbf{c}, \mathbf{d})$.

Oxidative stability is a crucial factor which affects the lifetime of HT-PEMs. Figure 5 reveals the residual weight of the membranes after immersing them in Fenton reagent for $48 \mathrm{~h}$ at $100{ }^{\circ} \mathrm{C}$. The pure linear OPBI membrane presents the maximum weight loss of about $20 \mathrm{wt} . \%$. Meanwhile, all crosslinked composite membranes display better oxidative stability than the OPBI membrane, with a small weight loss close to $3 \mathrm{wt} . \%$. The oxidation stability test results of the dry membranes showed excellent resistance to oxidation via radicals. However, given that these membranes are not swelling in water at all, all the degradation is taking part only on the surface, but not in the bulk of the membrane. In order to be closer to the conditions of reliable fuel cells, we tested the oxidation stabilities of the PA doped membranes. In the experiment, we set a gradient every $0.5 \mathrm{~h}$ to carry out the experiment. According to the observation, the PA doped OPBI membranes began to break after soaking in Fenton reagent for $2 \mathrm{~h}$ at $80^{\circ} \mathrm{C}$, and the PA doped semi-IPN/70PBI composite membranes began to break at $3.5 \mathrm{~h}$. We repeatedly washed the membranes soaked for $1.5 \mathrm{~h}$ with deionized water to wash away PA and dried them in a vacuum oven at $100{ }^{\circ} \mathrm{C}$. Compared with the weight of the dry membranes before PA adsorption, it is found that there was almost no weight loss, which indicates to some extent that the larger the adsorption amount of PA is, the more serious the swelling is, and the more unstable 
it is in Fenton reagent. Compared with PA doped OPBI membrane, PA doped semiIPN/70PBI composite has a better antioxidant stability, which is believed to be attributed to its crosslinked 3D network structure.

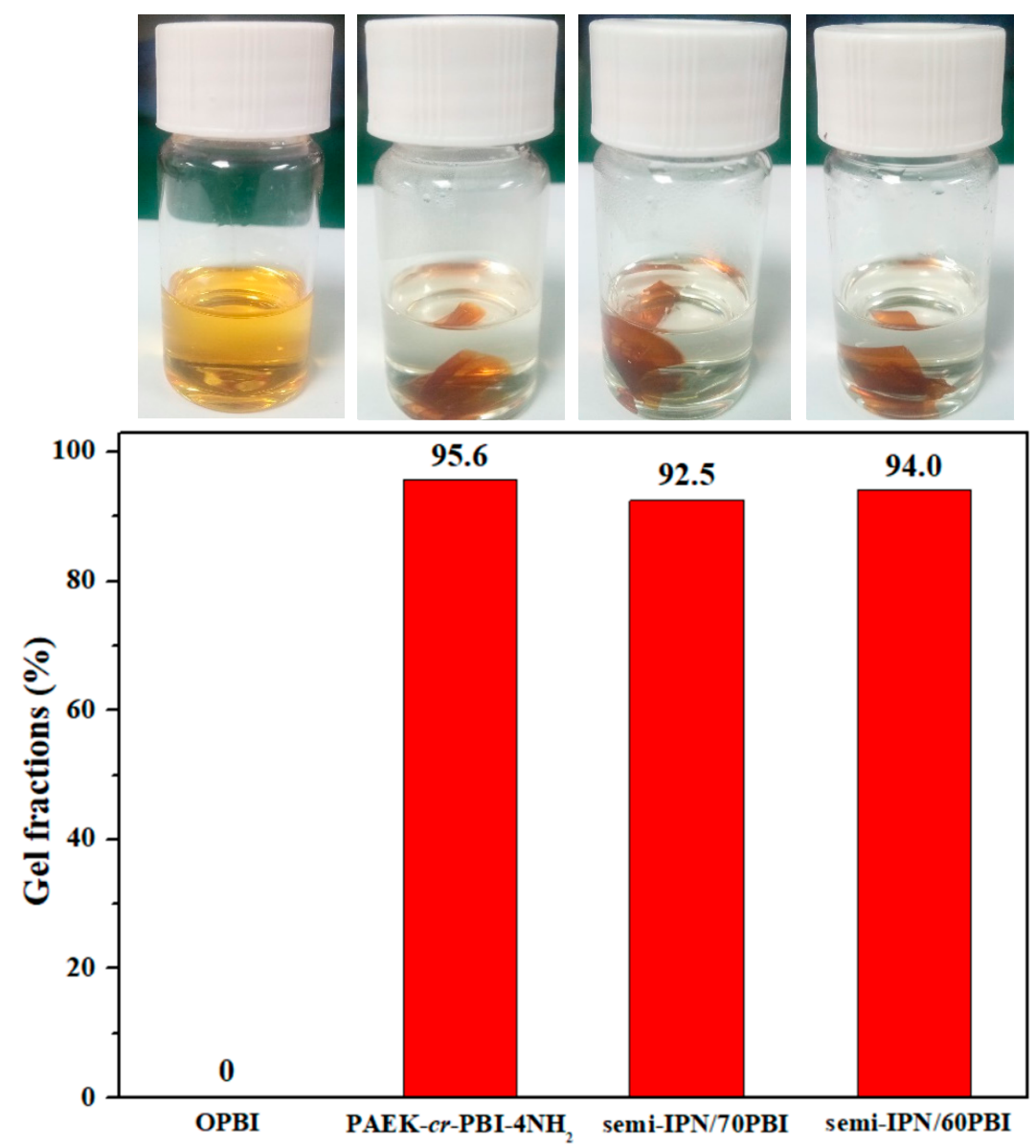

Figure 3. Gel fractions of OPBI, PAEK-cr-PBI, and semi-IPN/ $x$ PBI membranes after immersing in NMP at $100{ }^{\circ} \mathrm{C}$ for $48 \mathrm{~h}$.
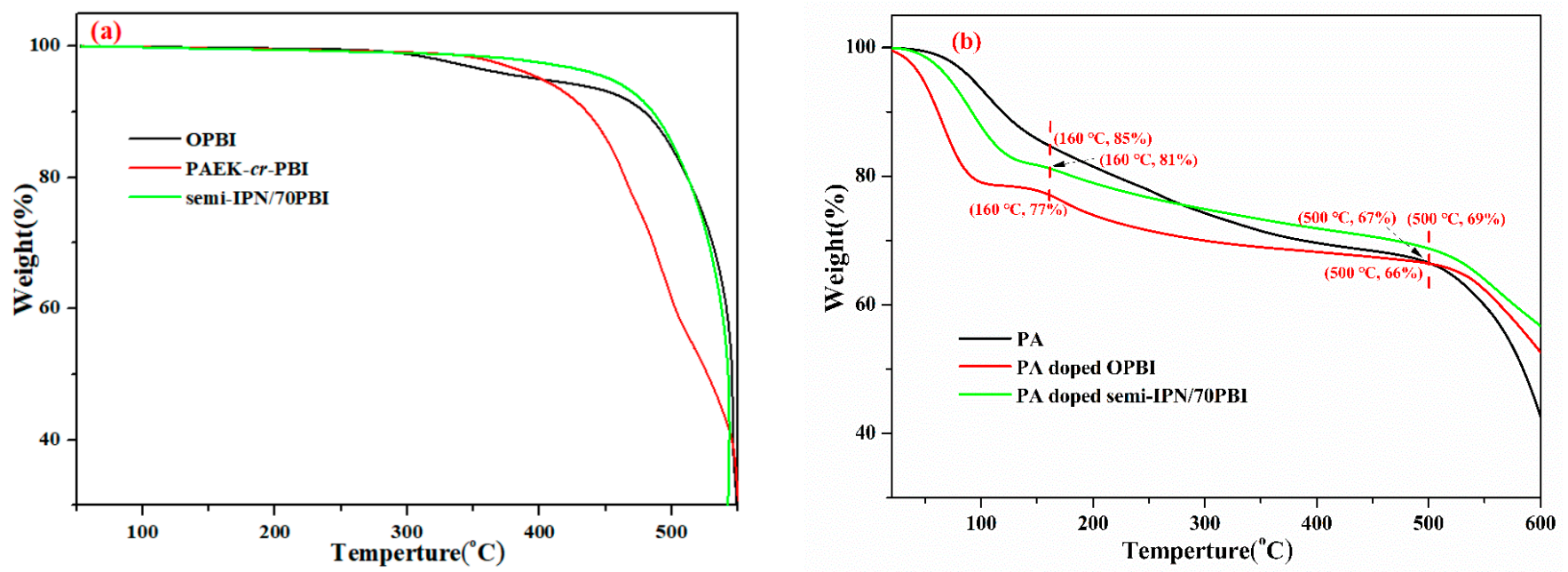

Figure 4. TGA curves of (a) PA undoped, and (b) PA doped OPBI, PAEK-cr-PBI, and semi-IPN/70PBI membranes under $\mathrm{O}_{2}$ flow at a heating rate of $10{ }^{\circ} \mathrm{C} \mathrm{min}^{-1}$. 
Table 1. 5\% weight loss temperature for dry membrane.

\begin{tabular}{cccc}
\hline Sample & OPBI & PAEK-cr-PBI & Semi-IPN/70PBI \\
\hline $\mathrm{T}_{-5 \% /}{ }^{\circ} \mathrm{C}$ & 399 & 401 & 453 \\
\hline
\end{tabular}

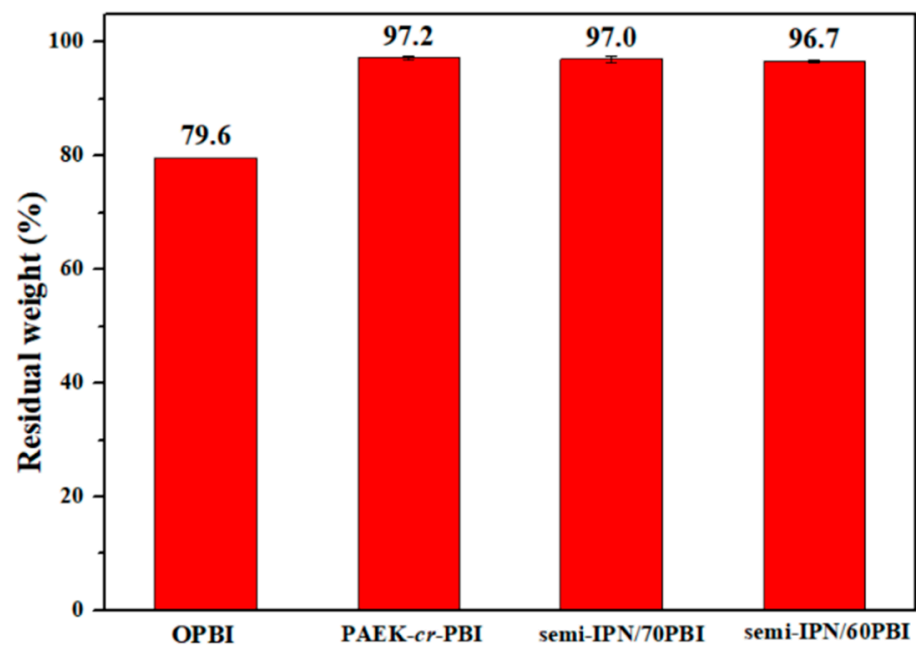

Figure 5. Residual weight of the membranes after treatment with Fenton reagent for $48 \mathrm{~h}$ at $80^{\circ} \mathrm{C}$.

\subsection{PA Doping Level, Volumetric Swelling Ratio, and Mechanical Properties}

For PA-doped HT-PEMs, ADL is the most important factor because proton transport is completed through the dissociation of PA molecules. Table 2 summarizes the ADLs and swelling ratios of PA doped membranes. It is apparent that the ADLs of PAEK-cr-PBI membranes are lower than those of OPBI membranes under the same PA doping condition due to the lower content of active imidazole groups. After PA doping, OPBI membrane exhibits a high volumetric swelling ratio of $140 \%$ with an ADL of $220 \%$. The high swelling ratio of HT-PEMs deteriorates the stability of MEA. By confining OPBI in the crosslinked network, the volumetric swelling ratios of semi-IPN/xPBI membranes are reduced to only $60 \%$ of that of OPBI and they still have comparative ADLs, which are necessary for the proton transportation.

Table 2. PA uptake, swelling, and mechanical properties of all PA doped membranes.

\begin{tabular}{ccccc}
\hline Membrane & PA Uptake (\%) & $\mathbf{S}_{\text {volume }} \mathbf{( \% )}$ & $\begin{array}{c}\text { Tensile } \\
\text { Strength (MPa) }\end{array}$ & Elongation (\%) \\
\hline OPBI & $219 \pm 3$ & $128 \pm 12$ & $5.1 \pm 0.8$ & $22.1 \pm 2.2$ \\
PAEK-cr-PBI & $121 \pm 2$ & $46 \pm 3$ & $20.4 \pm 1.2$ & $4.6 \pm 1.1$ \\
Semi-IPN/70PBI & $191 \pm 1$ & $78 \pm 3$ & $11.8 \pm 0.3$ & $20.3 \pm 4.8$ \\
Semi-IPN/60PBI & $179 \pm 5$ & $72 \pm 3$ & $12.8 \pm 0.2$ & $18.6 \pm 1.9$ \\
\hline
\end{tabular}

It is also vital for HT-PEMs to possess the required mechanical performance for use in HT-PEMFCs. The typical stress-strain curves of different membranes are depicted in Figure 6 and the detail data are displayed in Table 2. In general, in the case of crosslinked membranes, 3D networks can improve the interaction between chains, thus enhancing the mechanical properties of the membrane, and the test results are as expected. Due to the low PA adsorption, the PAEK-cr-PBI membrane exhibits a tensile strength of $19.2 \mathrm{MPa}$ and a lower elongation at fracture value of $5.7 \%$. For the linear OPBI membrane, the tensile strength is $5.1 \mathrm{MPa}$ which is ascribed to the plasticizing effect of the large amount of doped PA. Moreover, under the effect of the crosslinking structure, two PA doped semi-IPN $/ x$ PBI membranes reveal higher tensile strength, along with the values of $11.8 \mathrm{MPa}$ and $12.8 \mathrm{MPa}$, respectively, which are about 2.5 times higher than that of OPBI. 


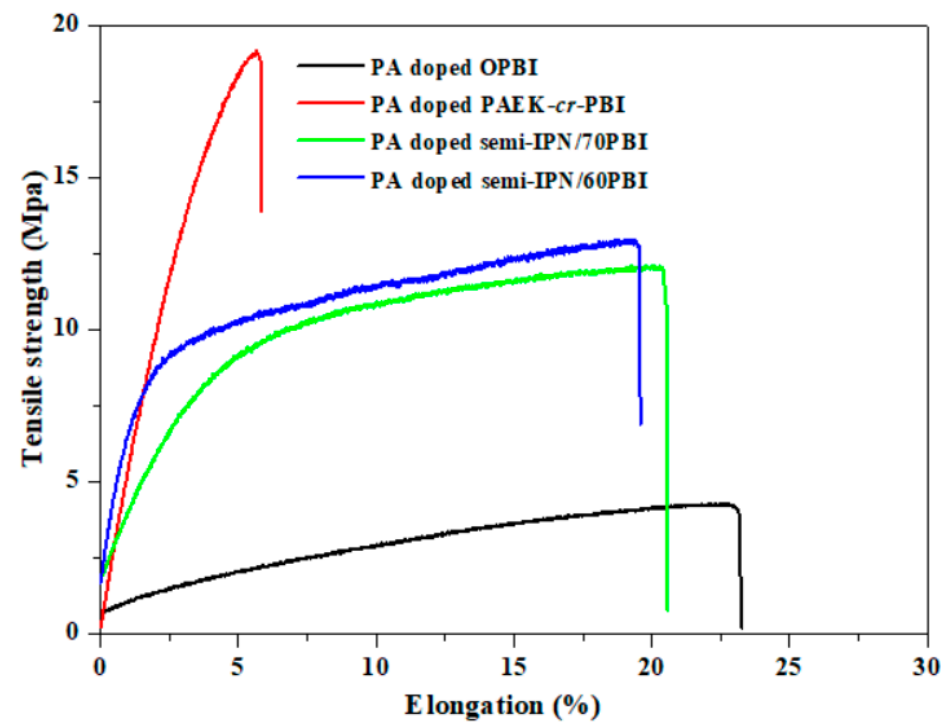

Figure 6. Stress-strain curves of PA doped membranes.

\subsection{Proton Conductivity}

The proton conductivities of the membranes were measured from $80{ }^{\circ} \mathrm{C}$ to $180{ }^{\circ} \mathrm{C}$ under anhydrous condition. As shown in Figure 7, the proton conductivities of all membranes increase with increasing temperature, and a slight decrease occurs above $160{ }^{\circ} \mathrm{C}$ which is ascribed to the dimerization of PA at this temperature [45]. The PA doped PAEKcr-PBI membrane has the lowest conductivity of $27 \mathrm{mS} \mathrm{cm}^{-1}$ at $160{ }^{\circ} \mathrm{C}$ as it has the lowest active group content. The proton conductivities of PA doped semi-IPN $/ x$ PBI are almost equivalent to those of the PA doped OPBI membrane, even though its ADL is lower than that of the OPBI membrane. The PA doped semi-IPN/70PBI possesses a proton conductivity of $53 \mathrm{mS} \mathrm{cm}^{-1}$ at $160{ }^{\circ} \mathrm{C}$, which is higher than that of the PA doped OPBI membrane $\left(49 \mathrm{mS} \mathrm{cm}^{-1}\right)$, indicating that the construction of a 3D crosslinked network with active imidazole groups is conducive to the formation of a well-connected proton conductivity channel.

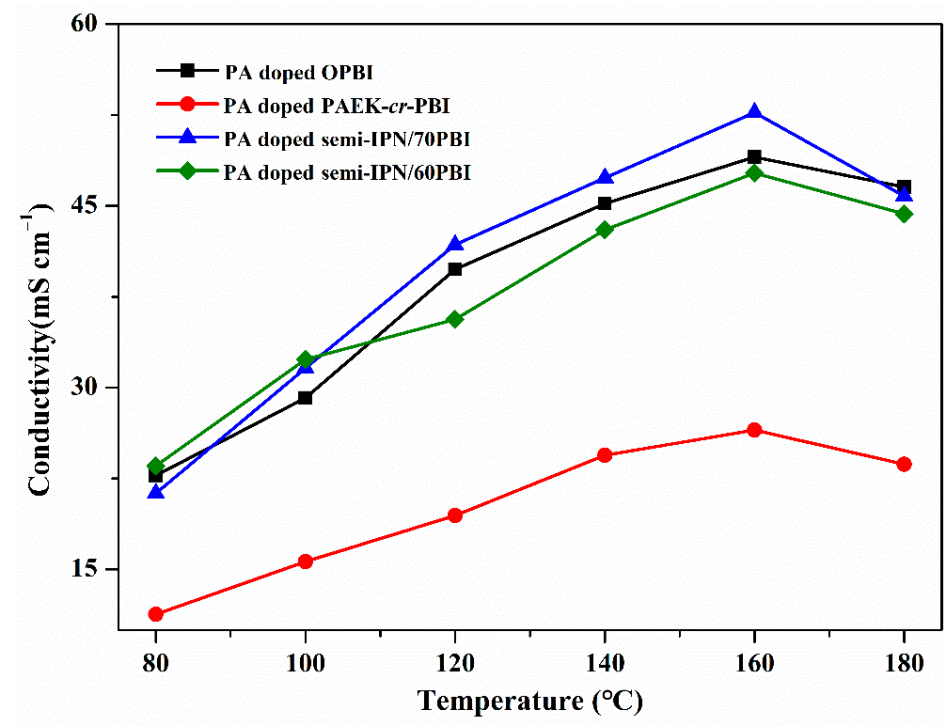

Figure 7. Proton conductivities of PA doped membranes.

\subsection{Single Fuel Cell Performance}

The PA doped semi-IPN/70PBI membrane with a high proton conductivity and excellent mechanical strength was selected to evaluate single fuel cell performance. Meanwhile, 
the PA doped OPBI membrane was also employed as a control. The effects of temperature, back pressure, and gas flow rate (SLPM) on single cell performance with the PA doped OPBI membrane were investigated, and the cell performances under different test conditions are shown in Figure 8a. The best performance of a single cell was obtained at $160{ }^{\circ} \mathrm{C}$ with a background pressure and high flow rate of $\mathrm{H}_{2}$ and $\mathrm{O}_{2}$. Figure $8 \mathrm{~b}$ reveals the polarization and power density curves of the single HT-PEMFCs with the PA doped OPBI and semi-IPN/70PBI membranes under the optimized condition. Compared to the pristine OPBI, the MEA with semi-IPN/70PBI displays a higher peak power density. The open-circuit voltages (OCVs) of MEAs with semi-IPN/70PBI and OPBI membranes are 0.982 and $0.788 \mathrm{~V}$, respectively, implying that semi-IPN/70PBI membranes possess a low gas permeability. At $160{ }^{\circ} \mathrm{C}$, along with flow rates of 250 and $500 \mathrm{~mL} \mathrm{~min}^{-1}$ for dry $\mathrm{H}_{2}$ and $\mathrm{O}_{2}$ at a backpressure of $0.03 \mathrm{MPa}$, semi-IPN/70PBI gives a maximum peak power density of $660 \mathrm{~mW} \mathrm{~cm} \mathrm{~cm}^{-2}$, which is notably $18 \%$ higher than that of the pristine OPBI membrane $\left(561 \mathrm{~mW} \mathrm{~cm}^{-2}\right.$ ) with almost the same ADLs. This result demonstrates that constructing a dense cross-linked 3D network substrate with active imidazole groups is a potential methodology to enhance the performance of HT-PEMFCs.
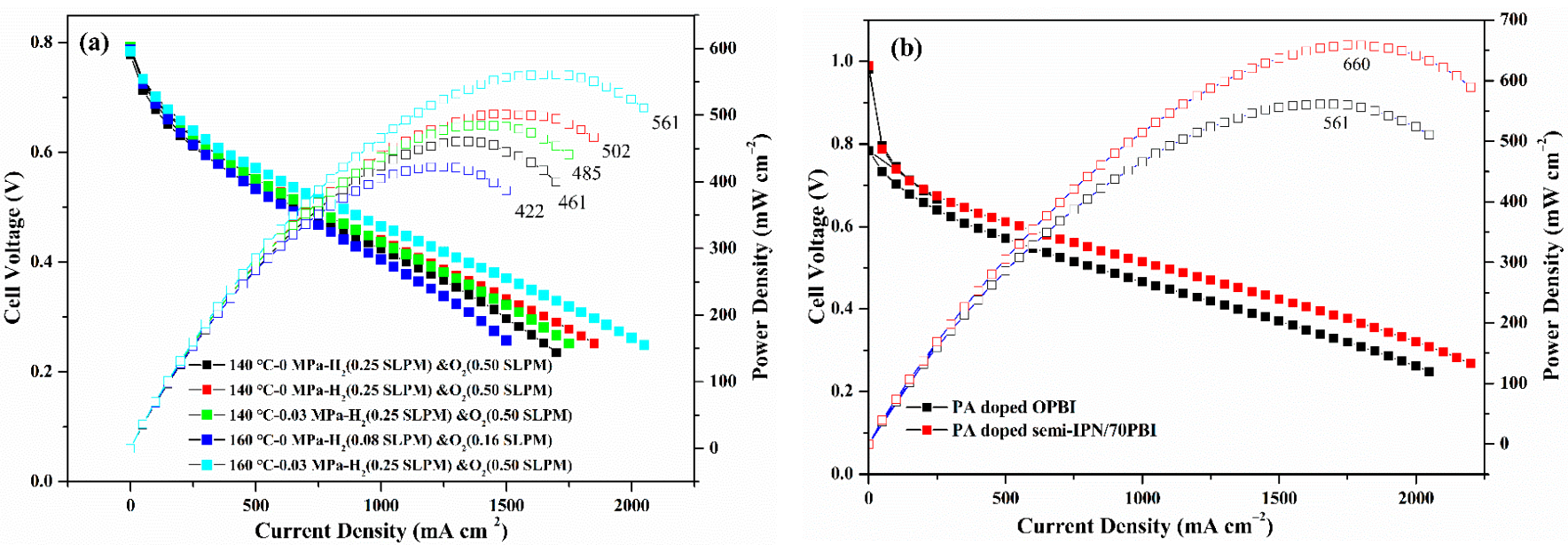

Figure 8. Polarization curves (solid symbols) and power densities (open symbols) of single fuel cells based on the (a) PA doped OPBI under different test conditions, and (b) PA doped OPBI and semi-IPN/70PBI membranes with flow rates of 250 and $500 \mathrm{~mL} \mathrm{~min}{ }^{-1}$ for dry $\mathrm{H}_{2}$ and $\mathrm{O}_{2}$ at a backpressure of $0.03 \mathrm{MPa}$. The thickness of PA doped OPBI and PA doped semi-IPN/70PBI is 65 and $48 \mu \mathrm{m}$, respectively.

\section{Conclusions}

In this work, it was shown that a series of semi-IPN/70PBI membranes with a semiinterpenetration network structure can be readily prepared using a solution casting method via succeeding stepwise heating. Due to the construction of a 3D crosslinked network, the properties of semi-IPN $/ x$ PBI such as oxidative stability, volumetric swelling ratio, mechanical properties, and proton conductivity were greatly enhanced compared with the pristine linear OPBI membrane. The PA doped semi-IPN/70PBI membrane shows a 2.5 times higher tensile strength $(11.8 \mathrm{MPa})$ and higher proton conductivity at $160{ }^{\circ} \mathrm{C}$ (53 mS cm ${ }^{-1}$ ) compared to the PA doped OPBI membrane. In particular, a single $\mathrm{H}_{2} / \mathrm{O}_{2}$ HT-PEMFC assembled with a semi-IPN/70PBI membrane reaches a maximum power density of $660 \mathrm{~mW} \mathrm{~cm}{ }^{-2}$ at $160{ }^{\circ} \mathrm{C}$ with flow rates of 250 and $500 \mathrm{~mL} \mathrm{~min}^{-1}$ for dry $\mathrm{H}_{2}$ and $\mathrm{O}_{2}$ at a backpressure of $0.03 \mathrm{MPa}$, which is $18 \%$ higher than that of the pristine OPBI membrane ( $561 \mathrm{~mW} \mathrm{~cm}^{-2}$ ) under the same test condition. In conclusion, this work demonstrates a feasible and effective method to construct a composite membrane with a $3 \mathrm{D}$ semi-interpenetration network structure bearing abundant active imidazole groups for potential and extensive application in HT-PEMFCs. 
Supplementary Materials: The following supporting information can be downloaded at: https: / / www.mdpi.com/article/10.3390/nano12050773/s1, Figure S1: FT-IR spectroscopy of model compound; Scheme S1: Possible reaction mechanism of model compound.

Author Contributions: Conceptualization, E.Q., S.W. and Y.M.; methodology, E.Q.; software, E.Q.; validation, E.Q., J.J. and S.W.; formal analysis, E.Q.; investigation, E.Q.; resources, S.W. and Y.M.; data curation, E.Q.; writing—original draft preparation, E.Q.; writing—review and editing, E.Q., M.X., D.H., S.H., Z.H., S.W. and Y.M.; visualization, E.Q.; supervision, S.W., Y.M.; project administration, S.W. and Y.M.; funding acquisition, S.W. and Y.M. All authors have read and agreed to the published version of the manuscript.

Funding: This research was funded by the National Key Research and Development Program (JapanChina Joint Research Program) (2017YFE0197900), and the National Key Research and Development Program (2018YFA0702002).

Data Availability Statement: Not applicable.

Conflicts of Interest: The authors declare no conflict of interest.

\section{References}

1. Guo, Z.; Xu, X.; Xiang, Y.; Lu, S.; Jiang, S.P. New anhydrous proton exchange membranes for high-temperature fuel cells based on PVDF-PVP blended polymers. J. Mater. Chem. A 2014, 3, 148-155. [CrossRef]

2. Kim, S.-K.; Kim, K.-H.; Park, J.O.; Ko, T.; Choi, S.-W.; Pak, C.; Chang, H.; Lee, J.-C. Highly durable polymer electrolyte membranes at elevated temperature: Cross-linked copolymer structure consisting of poly(benzoxazine) and poly(benzimidazole). J. Power Source 2013, 226, 346-353. [CrossRef]

3. Li, Q.; Aili, D.; Hjuler, H.A.; Jensen, J.O. High Temperature Polymer Electrolyte Membrane Fuel Cells: Approaches, Status, and Perspectives; Springer International AG Switzerland: Cham, Switzerland, 2016.

4. Rahman, S.; Masdar, M.S.; Rosli, M.; Majlan, E.H.; Husaini, T.; Kamarudin, S.; Daud, W. Overview biohydrogen technologies and application in fuel cell technology. Renew. Sustain. Energy Rev. 2016, 66, 137-162. [CrossRef]

5. Tsai, T.-H.; Ertem, S.P.; Maes, A.M.; Seifert, S.; Herring, A.M.; Coughlin, E.B. Thermally Cross-Linked Anion Exchange Membranes from Solvent Processable Isoprene Containing Ionomers. Macromolecules 2015, 48, 655-662. [CrossRef]

6. Bose, S.; Kuila, T.; Nguyen, T.X.H.; Kim, N.H.; Lau, K.-T.; Lee, J.H. Polymer membranes for high temperature proton exchange membrane fuel cell: Recent advances and challenges. Prog. Polym. Sci. 2011, 36, 813-843. [CrossRef]

7. Mamlouk, M.; Scott, K. A boron phosphate-phosphoric acid composite membrane for medium temperature proton exchange membrane fuel cells. J. Power Source 2015, 286, 290-298. [CrossRef]

8. Tian, X.; Wang, S.; Li, J.; Liu, F.; Wang, X.; Chen, H.; Wang, D.; Ni, H.; Wang, Z. Benzimidazole grafted polybenzimidazole cross-linked membranes with excellent PA stability for high-temperature proton exchange membrane applications. Appl. Surf. Sci. 2019, 465, 332-339. [CrossRef]

9. Kallem, P.; Drobek, M.; Julbe, A.; Vriezekolk, E.J.; Mallada, R.; Pina, M.P. Hierarchical Porous Polybenzimidazole Microsieves: An Efficient Architecture for Anhydrous Proton Transport via Polyionic Liquids. ACS Appl. Mater. Interfaces 2017, 9, 14844-14857. [CrossRef]

10. Rosli, R.E.; Sulong, A.B.; Daud, W.R.W.; Zulkifley, M.A.; Husaini, T.; Rosli, M.I.; Majlan, E.H.; Haque, M.A. A review of hightemperature proton exchange membrane fuel cell (HT-PEMFC) system. Int. J. Hydrogen Energy 2017, 42, 9293-9314. [CrossRef]

11. He, R.; Li, Q.; Xiao, G.; Bjerrum, N.J. Proton conductivity of phosphoric acid doped polybenzimidazole and its composites with inorganic proton conductors. J. Membr. Sci. 2003, 226, 169-184. [CrossRef]

12. Hu, M.; Ni, J.; Zhang, B.; Neelakandan, S.; Wang, L. Crosslinked polybenzimidazoles containing branching structure as membrane materials with excellent cell performance and durability for fuel cell applications. J. Power Source 2018, 389, 222-229. [CrossRef]

13. Kallem, P.; Eguizabal, A.; Mallada, R.; Pina, M.P. Constructing Straight Polyionic Liquid Microchannels for Fast Anhydrous Proton Transport. ACS Appl. Mater. Interfaces 2016, 8, 35377-35389. [CrossRef] [PubMed]

14. Lee, A.S.; Choe, Y.-K.; Matanovic, I.; Kim, Y.S. The energetics of phosphoric acid interactions reveals a new acid loss mechanism. J. Mater. Chem. A 2019, 7, 9867-9876. [CrossRef]

15. Wainright, J.S.; Wang, J.T.; Weng, D.; Savinell, R.F.; Litt, M. Acid-Doped Polybenzimidazoles: A New Polymer Electrolyte. mboxemphJ. Electrochem. Soc. 1994, 142, L121-L123. [CrossRef]

16. Li, X.; Ma, H.; Wang, P.; Liu, Z.; Peng, J.; Hu, W.; Jiang, Z.; Liu, B. Construction of High-Performance, High-Temperature Proton Exchange Membranes through Incorporating $\mathrm{SiO}_{2}$ Nanoparticles into Novel Cross-linked Polybenzimidazole Networks. ACS Appl. Mater. Interfaces 2019, 11, 30735-30746. [CrossRef]

17. Liu, F.; Wang, S.; Li, J.; Tian, X.; Wang, X.; Chen, H.; Wang, Z. Polybenzimidazole/ionic-liquid-functional silica composite membranes with improved proton conductivity for high temperature proton exchange membrane fuel cells. J. Membr. Sci. 2017, 541, 492-499. [CrossRef] 
18. Mader, J.A.; Benicewicz, B.C. Sulfonated Polybenzimidazoles for High Temperature PEM Fuel Cells. Macromolecules 2010, 43, 6706-6715. [CrossRef]

19. Quartarone, E.; Mustarelli, P. Polymer fuel cells based on polybenzimidazole/H3PO4. Energy Environ. Sci. 2012, 5, 6436-6444. [CrossRef]

20. Chandan, A.; Hattenberger, M.; El-Kharouf, A.; Du, S.; Dhir, A.; Self, V.; Pollet, B.G.; Ingram, A.; Bujalski, W. High temperature (HT) polymer electrolyte membrane fuel cells (PEMFC)—A review. J. Power Source 2013, 231, 264-278. [CrossRef]

21. Tian, D.; Gu, T.; Yellamilli, S.N.; Bae, C. Phosphoric Acid-Doped Ion-Pair Coordinated PEMs with Broad Relative Humidity Tolerance. Energies 2020, 13, 1924. [CrossRef]

22. Won, S.; Oh, K.; Ju, H. Numerical degradation studies of high-temperature proton exchange membrane fuel cells with phosphoric acid-doped PBI membranes. Int. J. Hydrogen Energy 2016, 41, 8296-8306. [CrossRef]

23. Hu, M.; Li, T.; Neelakandan, S.; Wang, L.; Chen, Y. Cross-linked polybenzimidazoles containing hyperbranched cross-linkers and quaternary ammoniums as high-temperature proton exchange membranes: Enhanced stability and conductivity. J. Membr. Sci. 2019, 593, 117435. [CrossRef]

24. Lee, H.-S.; Roy, A.; Lane, O.; McGrath, J.E. Synthesis and characterization of poly(arylene ether sulfone)-b-polybenzimidazole copolymers for high temperature low humidity proton exchange membrane fuel cells. Polymer 2008, 49, 5387-5396. [CrossRef]

25. Zuo, Z.; Fu, Y.; Manthiram, A. Novel Blend Membranes Based on Acid-Base Interactions for Fuel Cells. Polymers 2012, 4, 1627-1644. [CrossRef]

26. Suryani; Liu, Y.-L. Preparation and properties of nanocomposite membranes of polybenzimidazole/sulfonated silica nanoparticles for proton exchange membranes. J. Membr. Sci. 2009, 332, 121-128. [CrossRef]

27. Bai, H.; Wang, H.; Zhang, J.; Wu, C.; Zhang, J.; Xiang, Y.; Lu, S. Simultaneously enhancing ionic conduction and mechanical strength of poly(ether sulfones)-poly(vinyl pyrrolidone) membrane by introducing graphitic carbon nitride nanosheets for high temperature proton exchange membrane fuel cell application. J. Membr. Sci. 2018, 558, 26-33. [CrossRef]

28. Joseph, D.; Krishnan, N.N.; Henkensmeier, D.; Jang, J.H.; Choi, S.H.; Kim, H.-J.; Han, J.; Nam, S.W. Thermal crosslinking of PBI/sulfonated polysulfone based blend membranes. J. Mater. Chem. A 2017, 1, 409-417. [CrossRef]

29. Ossiander, T.; Perchthaler, M.; Heinzl, C.; Schönberger, F.; Völk, P.; Welsch, M.; Chromik, A.; Hacker, V.; Scheu, C. Influence of membrane type and molecular weight distribution on the degradation of PBI-based HTPEM fuel cells. J. Membr. Sci. 2016, 509, 27-35. [CrossRef]

30. Zkan, N.; Devrim, Y. Fabrication and Characterization of Cross-linked Polybenzimidazole Based Membranes for High Temperature PEM Fuel Cells. Electrochim. Acta 2017, 245, 1-13.

31. Søndergaard, T.; Cleemann, L.N.; Becker, H.; Aili, D.; Steenberg, T.; Hjuler, H.A.; Seerup, L.; Li, Q.; Jensen, J.O. Long-term durability of HT-PEM fuel cells based on thermally cross-linked polybenzimidazole. J. Power Source 2017, 342, 570-578. [CrossRef]

32. Yang, J.; Gao, L.; Wang, J.; Xu, Y.; Liu, C.; He, R. Strengthening Phosphoric Acid Doped Polybenzimidazole Membranes with Siloxane Networks for Using as High Temperature Proton Exchange Membranes. Macromol. Chem. Phys. 2017, 218. [CrossRef]

33. Yang, J.; Li, Q.; Cleemann, L.N.; Jensen, J.O.; Pan, C.; Bjerrum, N.J.; He, R. Crosslinked Hexafluoropropylidene Polybenzimidazole Membranes with Chloromethyl Polysulfone for Fuel Cell Applications. Adv. Energy Mater. 2013, 3, 622-630. [CrossRef]

34. Li, Q.; Pan, C.; Jensen, J.O.; Noyé, A.P.; Bjerrum, N.J. Cross-Linked Polybenzimidazole Membranes for Fuel Cells. Chem. Mater. 2007, 19, 350-352. [CrossRef]

35. Kim, S.-K.; Choi, S.-W.; Jeon, W.S.; Park, J.O.; Ko, T.; Chang, H.; Lee, J.-C. Cross-Linked Benzoxazine-Benzimidazole Copolymer Electrolyte Membranes for Fuel Cells at Elevated Temperature. Macromolecules 2012, 45, 1438-1446. [CrossRef]

36. Wang, S.; Zhao, C.; Ma, W.; Zhang, N.; Zhang, Y.; Zhang, G.; Liu, Z.; Na, H. Silane-cross-linked polybenzimidazole with improved conductivity for high temperature proton exchange membrane fuel cells. J. Mater. Chem. A Mater. Energy Sustain. 2013, 1, 621-629. [CrossRef]

37. Thomas, O.D.; Peckham, T.J.; Thanganathan, U.; Yang, Y.; Holdcroft, S. Sulfonated polybenzimidazoles: Proton conduction and acid-base crosslinking. J. Polym. Sci. Part A Polym. Chem. 2010, 48, 3640-3650. [CrossRef]

38. Nasef, M.M. Radiation-Grafted Membranes for Polymer Electrolyte Fuel Cells: Current Trends and Future Directions. Chem. Rev. 2014, 114, 12278-12329. [CrossRef]

39. Valtcheva, I.B.; Kumbharkar, S.C.; Kim, J.F.; Bhole, Y.; Livingston, A. Beyond polyimide: Crosslinked polybenzimidazole membranes for organic solvent nanofiltration (OSN) in harsh environments. J. Membr. Sci. 2014, 457, 62-72. [CrossRef]

40. Wang, S.; Zhang, G.; Han, M.; Li, H.; Ni, J.; Ma, W.; Li, M.; Wang, J.; Liu, Z.; Zhang, L.; et al. Novel epoxy-based cross-linked polybenzimidazole for high temperature proton exchange membrane fuel cells. Int. J. Hydrogen Energy 2011, 21, 2187-2193. [CrossRef]

41. An, D.; Wu, B.; Zhang, G.; Zhang, W.; Wang, Y. Gradiently crosslinked polymer electrolyte membranes in fuel cells. J. Power Source 2016, 301, 204-209. [CrossRef]

42. Anderson, L.J.; Yuan, X.; Fahs, G.B.; Moore, R.B. Blocky Ionomers via Sulfonation of Poly(ether ether ketone) in the Semicrystalline Gel State. Macromolecules 2018, 51, 6226-6237. [CrossRef]

43. Kumar, G.G.; Manthiram, A. Sulfonated polyether ether ketone/strontium zirconite@ $\mathrm{TiO}_{2}$ nanocomposite membranes for direct methanol fuel cells. J. Mater. Chem. A 2017, 5, 20497-20504. [CrossRef] 
44. Jiang, J.; Qu, E.; Xiao, M.; Han, D.; Wang, S.; Meng, Y. 3D Network Structural Poly (Aryl Ether Ketone)-Polybenzimidazole Polymer for High-Temperature Proton Exchange Membrane Fuel Cells. Adv. Polym. Technol. 2020, 2020, 1-13. [CrossRef]

45. Ma, W.; Zhao, C.; Lin, H.; Zhang, G.; Ni, J.; Wang, J.; Wang, S.; Na, H. High-temperature water-free proton conducting membranes based on poly(arylene ether ketone) containing pendant quaternary ammonium groups with enhanced proton transport. J. Power Source 2011, 196, 9331-9338. [CrossRef] 